\title{
A comparison of the relationships between progestin receptors and oestrogen receptors in neural and non-neural target tissues of the rat during the oestrous cycle
}

\author{
Seán THROWER and Louis LIM* \\ Department of Neurochemistry, Institute of Neurology, Queen Square, London WC1N 3BG, U.K.
}

(Received 1 May 1980)

\begin{abstract}
Similar cyclic changes in the content of nuclear oestrogen receptor occurred in the hypothalamus, cerebral cortex, uterus and pituitary during the oestrous cycle. The relationship of the unoccupied to the total nuclear oestrogen receptor at each phase was similar in all these tissues. However, cyclic changes in the content of the cytosol progestin receptor occurred only in the uterus and pituitary (where they paralleled changes in the nuclear oestrogen receptor), but not in the hypothalamus or cerebral cortex.
\end{abstract}

Oestrogens and progestins acting in target tissues appear to be intimately linked in their modes of action. In the rat uterus, progestins appear to inhibit the synthesis of oestrogen receptors de novo, whereas oestrogens induce the synthesis of progestin receptors. We are interested in the progestin receptor since it may serve as a potential marker for oestrogenic responses in our studies of the mode of action of oestrogen receptors, and as the probable mediator for the known actions of progestins in the regulation of the rat oestrous cycle, in particular acting at the level of the hypothalamus.

Work in this laboratory and others (Thrower \& Lim, 1978, 1980; MacLusky \& McEwen, 1978; Moguilewsky \& Raynaud, 1979) has demonstrated that normal rats have substantial concentrations of high-affinity specific progestin binding in the hypothalamus and cortex. This binding is absent in ovariectomized animals, and can be induced by treatment with oestradiol (MacLusky \& McEwen, 1978; Moguilewsky \& Raynaud, 1979). Despite reports that a similar specific high-affinity progestinbinding species in the hypothalamus apparently translocates in vivo from cytosol to nucleus in response to exogenous progesterone (Kato \& Onouchi, 1977), we have been unable to detect translocation in our rats in response to progesterone administration, nor indeed did priming with oestradiol increase the apparent content of progestin binding in the hypothalamus or cortex (Thrower \& Lim, 1980; the present paper).

To evaluate the significance of these observations, we studied the progestin binding in neuronal

\footnotetext{
* To whom reprint requests should be addressed.
}

tissues in relation to the natural changes in sex steroid concentrations and in the patterns of nuclear and cytosol oestrogen receptor content associated with the oestrous cycle, comparing these to measurements (in the same animals) made on other target tissues also known to be involved in the processes leading to ovulation: specifically the uterus, ovary and pituitary. By using identical techniques of receptor measurement in each tissue, we attempted to establish whether the apparent insensitivity of the neuronal progestin receptor to progesterone and oestradiol was an artefact either of assay or of treatment, or whether it represented the normal physiological state.

The measurements of nuclear oestrogen receptors in these animals distinguished occupied receptors (receptor bound to oestradiol) from unoccupied receptors (Zava \& McGuire, 1977; Levy et al., 1980), in order to examine whether tissues other than uterus or hypothalamus (White \& Lim, 1978; White et al., 1978a; S. Thrower, C. Neethling \& L. Lim, unpublished work) contained unoccupied nuclear receptors, and to examine their respective roles in mediating the oestrogenic response (indicated by changes in progestin receptor content) to changes in circulating oestrogens in the untreated animal.

The results reported in the present paper show that all tissues showed qualitatively a very similar response of the nuclear oestrogen receptor, occupied and unoccupied, to the changing oestrogen concentrations throughout the cycle. In each of the non-neural tissues, cytosol progestin receptor concentration also changed in a manner consistent with oestrogenic regulation of progestin 
receptor content, but in the neural tissues, hypothalamus and cortex, there was no change in progestin binding during the cycle.

\section{Experimental}

Adult (60 days) and immature (29-31 days) female Wistar rats were bred in our laboratory. $\left[1,2,6,7-{ }^{3} \mathrm{H}\right]$ Progesterone (sp. radioactivity $80-100$ $\mathrm{Ci} / \mathrm{mmol}$ ) and $\left[2,4,6,7(\mathrm{n})-{ }^{3} \mathrm{H}\right]$ oestradiol- $17 \beta$ (sp. radioactivity $80-100 \mathrm{Ci} / \mathrm{mmol}$ ) were from The Radiochemical Centre, Amersham, Bucks., U.K.

\section{Measurements of receptor content}

For each experiment, adult animals were phased as previously described (White et al., 1978b) and groups of six to eight animals from each phase were pooled and the hypothalamus, cortex, pituitary, ovaries and/or uterus were removed into ice-cold buffer. Initially the buffer used was $10 \mathrm{mM}$-Tris/ $\mathrm{HCl}$ (pH 7.4) $/ 0.25 \mathrm{M}$-sucrose $/ 1 \mathrm{~mm}-\mathrm{CaCl}_{2}$ (TSC buffer), but in later experiments we used $10 \mathrm{~mm}$-Tris $/ \mathrm{HCl}$ $(\mathrm{pH} 7.4) / 1 \mathrm{~mm}$-EDTA/glycerol $\quad 10 \% \quad\left(\mathrm{v} / \mathrm{v} / 1 \mathrm{mM}^{-}\right.$ dithiothreitol (TEGD buffer).

Progestin and oestrogen receptor contents in cytosol preparations were measured by spheroidal hydroxyapatite chromatography (Thrower \& Lim, 1980).

Nuclear oestrogen receptor content was measured as follows. A crude nuclear preparation was washed three times with $20 \mathrm{ml}$ of buffer and incubated with $1 \mathrm{nM}$ - (hypothalamus, cortex and pituitary) or $5 \mathrm{nM}$ (ovary and uterus) $\left[{ }^{3} \mathrm{H}\right]$ oestradiol, with or without a 200 -fold excess of diethylstilboestrol, for $30 \mathrm{~min}$ at $4^{\circ} \mathrm{C}$ (unoccupied receptor) or $37^{\circ} \mathrm{C}$ (unoccupied + occupied receptor) (Zava \& McGuire, 1977; Levy et al., 1980). After two washes with TSC or TEGD buffer the nuclear pellets were extracted for $1 \mathrm{~h}$ at $4^{\circ} \mathrm{C}$ with $1 \mathrm{M}-\mathrm{KCl}$. When the supernatant extract was subsequently assayed for $\left[{ }^{3} \mathrm{H}\right]$ oestradiol binding by Sephadex LH-20 chromatography (White et al., 1978b), the amount of non-specific binding (measured in the samples containing diethylstilboestrol) had decreased to very low values, permitting accurate estimation of specific (receptor) binding in all tissues.

\section{Treatment of data}

In presenting the results it was necessary to take into account a systematic breakdown of nuclear receptor in all tissues at $37^{\circ} \mathrm{C}$ compared with $4{ }^{\circ} \mathrm{C}$, and a change in the buffer used midway through the series of experiments. Since all experiments were internally consistent and showed the same pattern of results, the results have been treated by expressing all phase measurements relative to the average value across the cycle $(=1.0)$ (Fig. 1) and so that different experiments could be combined to give a mean \pm standard deviation for most tissues to enable data from different tissues to be plotted together in Fig. 2. This treatment of data has been used previously for assessing changes throughout the oestrous cycle (White et al., 1978b).

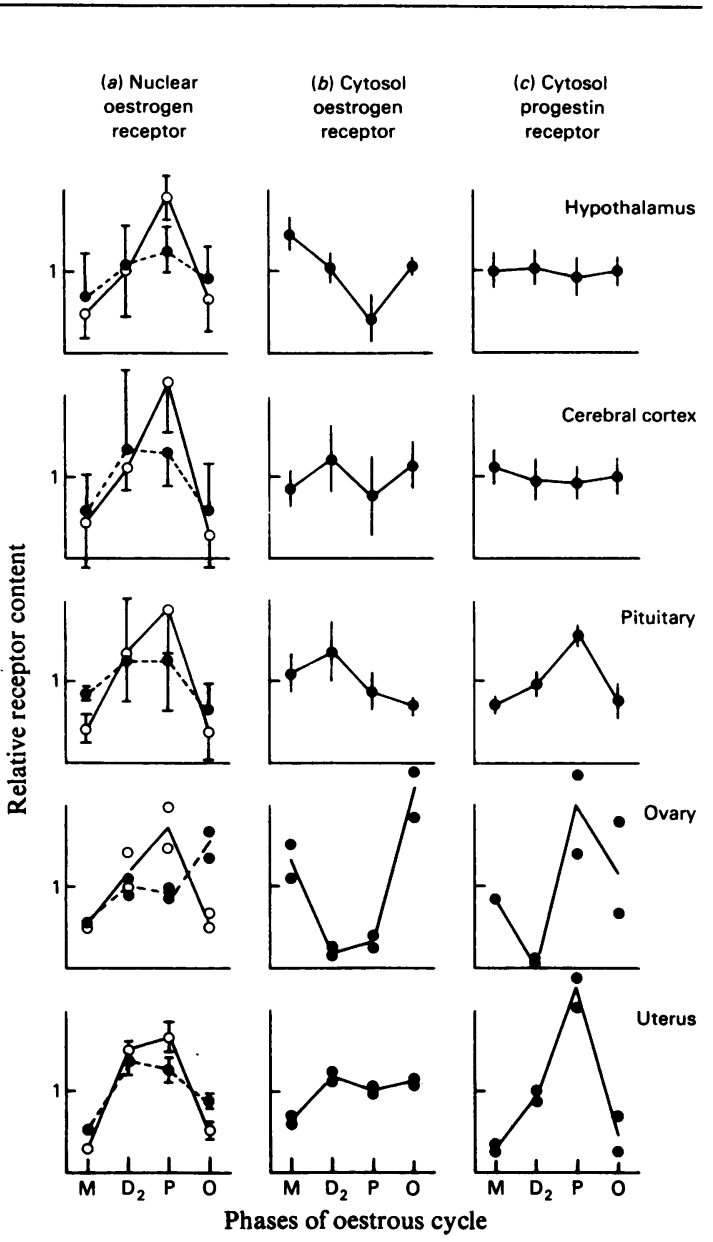

Fig. 1. The relationship between oestrogen receptors and cytosol progestin receptors during the oestrous cycle Measurements of receptor content and treatment of data are described in the Experimental section. Receptor content in each phase is expressed relative to the mean value of all four phases. Bars represent S.D. for the means derived from four to five (hypothalamus), three to four (cortex, pituitary) and three (uterus) separate determinations. In the case of the ovary, data from two separate experiments are shown. For the uterus, values for the two separate experiments for the cytosol oestrogen receptor are consistent with our previous results (White et al., 1978h); those for the cytosol progestin receptors are consistent with the findings of Vu Hai et al. (1978). In $(a)$, symbols represent: $\bullet$, unoccupied sites; $O$, occupied sites. Abbreviations used: M, metoestrus; $D_{2}$, late dioestrus; $P$, pro-oestrus; $O$, oestrus. 

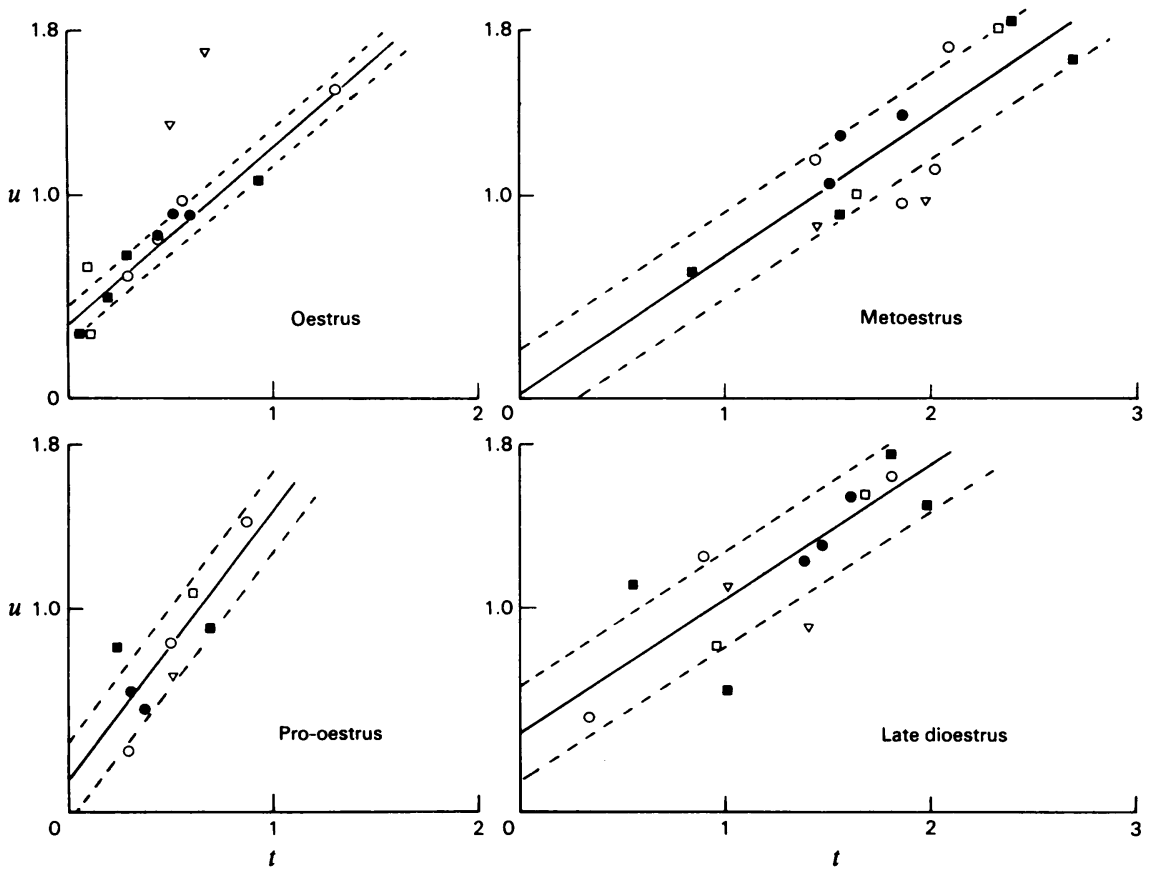

Fig. 2. The relationship between unoccupied and occupied oestrogen receptor content during the oestrous cycle Individual measurements of unoccupied and total oestrogen receptor content, treated as described under 'Treatment of data', were grouped according to phase and plotted as unoccupied $(u)$ versus total '( $t)$ : receptor content. Data from all tissues were plotted. In each case the data (excluding those from the ovary; see the Results and Discussion sections) grouped as a linear plot, for which the gradient was calculated as means \pm S.D. by linear regression analysis. Values in parentheses refer to numbers of determinations. (1) Oestrus: $u / t=0.854 \pm 0.09(13), r=0.96, P<0.001 ;(2)$ metoestrus: $u / t=1.297 \pm 0.19$ (8), $r=0.84, P<0.01$; (3) dioestrus: $u / t=0.654 \pm 0.23(12), r=0.84, P<0.001 ;(4)$ pro-oestrus: $u / t=0.675 \pm 0.21$ (13), $r=0.84, P<0.001$. Symbols: $O$, hypothalamus; $\square$, cortex; $\square$, pituitary; $O$, uterus; $\nabla$, ovary (not included in regression analysis).

\section{Results}

\section{Oestrogen and progestin receptor changes during the oestrous cycle}

Nuclear oestrogen receptors. In each of the target tissues studied, neuronal and non-neuronal, the same pattern of change in total nuclear oestrogen receptor that occurred during the oestrous cycle was observed (Fig. 1a). There were low concentrations of receptor during oestrus and the start of the new cycle (metoestrus/early dioestrus), followed by a 3 -fold increase through late dioestrus to a peak at proestrus. This pattern matched the changes in ovarian secretion and plasma concentration of oestrogens (Brown-Grant et al., 1970; Yoshinaga et al., 1969). The unoccupied nuclear receptor population showed a similar but less pronounced pattern in all tissues except the ovary; however, the changes in this fraction were not statistically significant when expressed in this way, except in the uterus.

From the absolute data we obtained there appeared to be a characteristic relationship for each phase between total receptor content and unoccupied receptor content: all the tissues except the ovary appeared to show this. The normalized data from Fig. 1(a) enabled us to plot data from all the tissues on to the same graph (of total-versus-unoccupied receptor content; Fig. 2). This confirmed that there was a highly significant and characteristic relationship between unoccupied and total receptor, individual to each phase, and shared by all the tissues except the ovary.

Within the normal range of amount of total receptor across the cycle, it is clear that even though the amount of unoccupied receptor at late dioestrus and proestrus was higher than at oestrus and metoestrus, the proportion of total receptor that is unoccupied was significantly lower, in most tissues examined. Consequently, the changes in occupied nuclear receptor in these tissues must be even more marked than those observed for total receptor, with the major increase occurring between late dioestrus and proestrus, rather than during late dioestrus (as we have already reported for the uterus and hypothalamus; White et al., 1978b). 
The exception to this pattern was the ovary, as would be expected from the high concentrations of oestrogens in the tissue during late dioestrus and proestrus: this endogenous steroid, binding to unoccupied receptor during preparation of the tissue subfractions obtained during these phases, would produce the effect of an apparent increase in unoccupied receptor during the oestrus phase, as was observed (Fig. 1a).

Cytosol oestrogen receptor. The concentration of oestrogen receptor in cortical cytosol was very low and showed no significant pattern through the cycle (Fig. 1b). By contrast, in the hypothalamus, receptor content was greatly decreased at proestrus, confirming our previous report (White et al., 1978b), recovered during oestrus, and was maximal during metoestrus. Pituitary cytosol showed a similar pattern, except that recovery after proestrus was delayed until metoestrus. Uterine oestrogen receptor varied with the wet weight of the tissue and was lowest during metoestrus. In ovary there was a marked decrease in apparent receptor content to very low values during late dioestrus and proestrus, but this pattern, like that of the nuclear receptor, may be an artefact of the high oestrogen concentrations in the tissue at this time.

Cytosol progestin receptors. In the uterus, ovary and pituitary, the content of cytosol progestin receptor (as measured by specific binding to spheroidal hydroxyapatite) reached a peak during proestrus and decreased during oestrus and metoestrus (Fig. 1c). However, in the neuronal tissues, hypothalamus and cortex, there was no change in apparent progestin receptor at any stage of the cycle.

\section{Effect of progesterone or oestrogen administration on progestin receptors of neural tissues}

In 35-day-old immature females administration of $1 \mathrm{mg}$ of progesterone intraperitoneally had no effect on hypothalamic or cortical progestin receptor content or distribution up to $6 \mathrm{~h}$ after injection. In both tissues the cytosol receptor at all times was $0.5 \pm 0.1 \mathrm{pmol} / \mathrm{block}$, whereas nuclear receptors remained undetectable. The administration of $1 \mathrm{mg}$ of progesterone to pooled groups of adult female rats was also without any effect on the concentration of cytosol progestin receptors in hypothalamic or cortical tissue. In the uterus of both immature and mature rats, this injection of progestin produced a marked decrease in cytosol progestin receptors (results not shown) as also shown previously by others working on a variety of animals (Milgrom $e t$ al., 1973; Feil \& Bardin, 1975; Walters \& Clark, 1978; Isomaa et al., 1979).

Administration of $2.5 \mu \mathrm{g}$ of oestradiol to immature 30-day-old females 24 and $48 \mathrm{~h}$ before killing had no effect on the cytosol progestin receptor content of neural tissues, although in the uterus it produced a 3-fold increase in cytosol progestin and oestrogen receptor content (results not shown).

\section{Discussion}

Our results show that the concentration of cytosol progestin receptors in neural tissues, unlike that in non-neural tissues, was not directly related to changes in the nuclear oestrogen receptor content. However, although increases in circulating oestrogen concentrations did not appear to be involved in the production/synthesis of neural progestin receptors, we cannot exclude the possibility that in neural tissues there is sufficient basal oestrogen for maintenance of progestin receptor. Nevertheless, the operations of the neural progestin receptor system were different from other progestin target tissues in that progestins did not effect receptor translocation. In the uterus it has been suggested that the decline in cytosol progestin receptors at oestrus is partly related to progesterone-induced translocation and loss brought by the ligand itself (Milgrom, 1978) and partly to decreased oestrogenic stimulation (Kurl \& Borthwick, 1979; Vu Hai et al., 1978). Differences in the behaviour of neural and non-neural cytosol progestin receptors cannot be attributed to the presence of different progestin receptors in the two types of tissue, as we have used identical methods for measuring progestin receptor. This method, involving spheroidal hydroxyapatite chromatography, was used to demonstrate that the characteristics of progestin binding to neural and uterine receptors were similar (Thrower \& Lim, 1980).

Our previous studies on the uterus and hypothalamus (White et al., 1978b) have pointed out differences in the intracellular relationships of the oestrogen receptor in the uterus and hypothalamus. This present study, showing differences in the behaviour of progestin receptors and in the probable role of nuclear oestrogen receptors in progestin receptor synthesis, provides further evidence for dissimilarities in the operations of the sex steroid receptor system between neural and non-neural tissues.

We thank Grace Shen and Mark Habershon for expert technical assistance, and the Medical Research Council and the Brain Research Trust for support of the work.

\section{References}

Brown-Grant, K., Exley, D. \& Naftolin, F. (1970) $J$. Endocrinol. 48, 295-296

Feil, P. D. \& Bardin, C. W. (1975) Endocrinology 97, 1398-1407

Isomaa, V., Isotalo, H., Orava, M. \& Janne, O. (1979) Biochim. Biophys. Acta 585, 24-33

Kato, J. \& Onouchi, T. (1977) Endocrinology 101, 920-928 
Kurl, R. N. \& Borthwick, R. M. (1979) J. Endocrinol. 83, 41-51

Levy, C., Mortel, R., Eychenne, B., Robels, P. \& Baulieu, E. E. (1980) Biochem. J. 185, 733-738

MacLusky, N. J. \& McEwen, B. S. (1978) Nature (London) 274, 276-278

Milgrom, E. (1978) in Receptors in Hormone Acticn (O'Malley, B. W. \& Birnbaumer, L., eds.), vol. 2, pp. 473-490, Academic Press, London

Milgrom, E., Thi, L., Atger, M. \& Baulieu, E.-E. (1973) J. Biol. Chem. 248, 6366-6374

Moguilewsky, M. \& Raynaud, J.-P. (1979) Brain Res. 164, 154-175

Thrower, S. \& Lim, L. (1978) Biochem. Soc. Trans. 6, 1012-1014

Thrower, S. \& Lim, L. (1980) Biochem. J. 186, 295-300
Vu Hai, M. T., Logeat, F. \& Milgrom, E. (1978) $J$. Endocrinol. 76, 43-48

Walters, M. R. \& Clark, J. H. (1978) Endocrinology 103. 601-609

White, J. O. \& Lim, L. (1978) Biochem. Soc. Trans. 6, 1310-1312

White, J. O., Neethling, C. \& Lim, L. (1978a) Abstr. Proc. Eur. Soc. Neurochem. (Neuhoff, V., ed.), vol. 1, p. 622, Verlag-Chemie, Weinheim

White, J. O., Thrower, S. \& Lim, L. (1978b) Biochem. J. 172, 37-47

Yoshinaga, K., Hawkins, R. A. \& Stocker, J. F. (1969) Endocrinology 85, 103-112

Zava, D. T. \& McGuire, W. L. (1977) J. Biol. Chem. 252 , 3703-3708 